\title{
Implementing of Academic Text in Advanced Grammar Learning
}

\author{
Rifari Baron
}

Posgraduate Program of Universitas Indraprasta PGRI Jakarta, Indonesia

Correspondence: Rifari Baron, Universitas Indraprasta PGRI Jakarta, Indonesia. e-mail: rifari.baron@unindra.ac.id

Received: March 21, 2020

Revised: April 15, 2020

Accepted: April 17, 2020

DOI: $10.29408 /$ veles.v4i1.1994

URL: http://dx.doi.org/10.29408/veles.v4i1.1994

\begin{abstract}
Grammar has the main role in English language learning. It can be given an impact on English language skill mastery. The purposes of this study were to find deeply comprehending on grammar mastery using academic text. The method of study used a one-group experimental design. The sample was 25 students in the English Language Program at Universitas Indraprasta Jakarta. The sample was taken using purposive sampling. Essay test and observation technique were the instruments used in collecting the data. The data analysis used t-test paired two samples for means. The finding revealed that the students have a significant increase in scores from the pre-test and post-test results. Here, there was an increase of 33.6 points from pretest to posttest. The average score for pretest was 49.04 and the average score for posttest was 82.6. While the result of t-test paired two samples for means was $t$ Stat < t-table $(-19.5164<2.0638)$. It means that academic text gave more information deeply to identify English structure. The results of this study also have implications for improving students' reading skills, especially at the level of reading comprehension and vocabulary mastery.
\end{abstract}

Keywords: Academic-text, English, grammar, learning

\section{Introduction}

Advanced Grammar course is one of the courses that must be mastered by postgraduate students at English Language Program Universitas Indraprasta Jakarta. It provides a deep understanding of basic grammatical knowledge. Grammar is one of the foundations in language. Without grammar, language cannot exist. In language teaching, there is no controversy over the rules of teaching grammar. However, many problems are related to explicit grammar teaching models through the use of language. For postgraduate students, the learning process is directed at the practice of understanding grammar in the text. Researchers have debated whether grammar should be taught in the classroom and students, for their part, have generally looked upon grammar instruction as a necessary evil at best, and an avoidable burden at worst (Al-Mekhlafi \& Nagaratnam, 2011). The grammar teaching approach has experienced many things 
change. These changes, caused by several theoretical and empirical developments in the field, have not been organized and have been characterized by many pendulum swings. They can be seen in three general teaching approaches, starting with a teaching approach that is conceptualized in terms of methods with an exclusive focus on grammar, continues later as a type of meaningful communication exposure, and appears more recently as a series of teaching choices with a focus on grammar and meaning (Nassaji \& Fotos, 2011).

The results of observations in teaching grammar indicate problems with students' understanding of grammar content when identifying detailed grammatical structures and writing academic texts. Therefore, the grammar learning process is directed to practice using academic texts or academic articles, so that students become more understanding. Sentence construction is the most difficult learning process faced by students during the writing process. Most students make incorrect sentences in their recount text (Nurhayati, 2015). One distinctive feature of pedagogical grammar is that it facilitates awareness about the relationship of grammatical structure to the meaning and intent of the speaker/writer (Brown \& Kachru, 2006; Robertson, Macdonald, Starks, \& Nicholas, 2018). As said by Myhill, Jones, \& Watson (2013) that grammatical pedagogical content knowledge is more important than grammatical content knowledge in supporting meaningful teaching and learning about writing. Thus, grammar learning explicitly has a good influence on increasing knowledge of second grammar (Nazari, 2013). Grammar also gives awareness to students in using logic to understand discourse or events that occur (Teruya, 2009). A key aspect of grammar acquisition for second language learners involves learning how to make the right connection between grammatical forms and the meanings they usually mark (Batstone \& Ellis, 2009).

Deductive grammar teaching is slightly more effective than inductive teaching although this difference is not significant according to statistical data. The other main finding of this research is that lecturers feel better when they teach grammar deductively. These findings indicate that in teaching grammar to adult students, lecturers must be aware of the needs and perceptions of their students (Sik, 2015). There is an influence of mastery of local grammar in making academic writing. the practice of local grammar analysis helps to further increase the awareness of academic writers about the nature of the language patterns used, not only in terms of lexical-grammatical patterns but also discourse-semantic patterns (Su \& Zhang, 2020).

From previous studies, many discussed the role of grammar in improving writing or understanding of language, the application of methods in grammar language teaching and the controversy of grammar teaching in the classroom and outside the classroom. Therefore, this research is focused on the use of academic texts to improve students' knowledge of grammar. This research needs to be done for several reasons, such as academic texts providing facilities for understanding formal grammar, grammar is learned more practically directly, and students can carry out two activities namely identification of correct English grammatical structures and making correct academic writing. Thus, this research provides a novelty that has not been previously discussed. If all this time the research has been done by writing or writing to understand grammar, but this research, in turn, leads students to practice directly understanding deeper grammar in 
academic texts. The purpose of the study was to increase Advanced Grammar learning using academic text.

\section{Method}

The study used experimental research using the one-group experimental design. It is a onegroup pretest-posttest design. The design of one pretest and posttest was a quasi-experimental research design in which the same dependent variable was measured in one participant group before the pretest and after the posttest treatment was given. This study used a one-group pretest and posttest design to minimize problems that might arise during the study due to the absence of a control or comparison group. Through this design, this study can compare the ability of students before and after receiving treatment

\subsection{Participants}

The participant in this study was postgraduate students in the English Language Program at Universitas Indraprasta Jakarta. The sample is taken using purposive sampling. Purposive sampling is the deliberate selection of informants based on their ability to explain a particular theme, concept, or phenomenon (Robinson, 2014). This study determined the sample by the theme under study, which is related to the equitable improvement of students' understanding of advanced grammar. 25 students are participant in the research process. The study was conducted in August 2019 until January 2020.

\subsection{Data Collection}

\subsubsection{The instrument of Collecting Data}

The process of learning in advanced grammar through academic texts is taken from the TOEFL book on the reading skills section. 10 texts are used for the learning process for 10 meetings. At the initial meeting, the researcher determined 1 academic text from the TOEFL book to be used as an advanced grammar test and in the final meeting also took 1 academic text as the final test. The two texts have different topics. The two texts used to measure sentence mastery and discourse mastery include phonological forms, lexical forms, morphosyntactic forms, cohesive forms, information management firms, and interactional forms (Purpura, 2004). The test given is in the form of essays

\subsubsection{Techniques for Collecting Data}

The process of collecting data used essay test and observation. The test gave to the students before and after using academic text in advanced grammar. Here are the items of test:

Table 1. Components of Grammar Test

\begin{tabular}{lll}
\hline No & Components & Amounts of items \\
\hline 1 & Phonological forms & 4 \\
2 & Lexical forms & 4 \\
3 & Morphosyntactic forms & 5 \\
4 & Cohesive forms & 4 \\
5 & Information management forms & 4
\end{tabular}


while the observation was used in the teaching and learning process to find the students' progress in learning.

\subsection{Data Analysis}

Technique analysis data used t-test paired two samples for means. Calculation of t-test data analysis used the formula application in Excel. It used to know the students' mastery in grammar learning.

\section{Results}

Data obtained from the pretest and posttest were analyzed and presented in the form of descriptive statistics. The following results are descriptive statistical calculations;

Table 2. Statistic Descriptive of English Advanced Grammar Test

\begin{tabular}{lll}
\hline & Pre-test & Post-test \\
\hline Average & 49.04 & 82.6 \\
Median & 68.5 & 82 \\
Mode & 85 & 85 \\
Standard Deviation & 17.707 & 4.409 \\
Sample Variance & 46.37 & 20.26 \\
Minimum & 32 & 76 \\
Maximum & 61 & 90 \\
\hline
\end{tabular}

Descriptive statistical data presented in table 1 concluded there was an increase of 33.6 for the average score which could be interpreted that there was a significant change in students' understanding of English grammar. This is also known from the greatest score on the post-test results of 90 . It is a very satisfying score. Based on that data, here is the graph of pre-test and posttest.

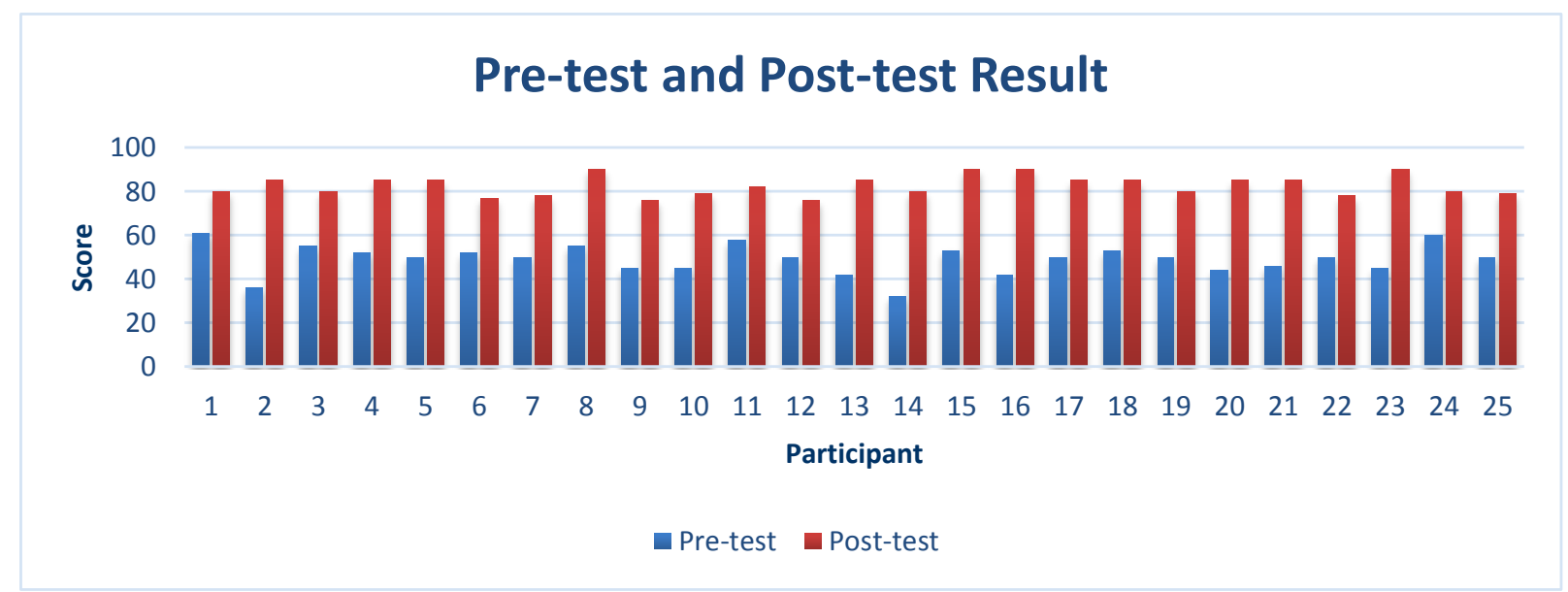

Graph 1. The differences Score of Test between Pre-test and Post-test 
The test results on the Advanced Grammar course have shown very good development from every student. From 25 students showed an increase in grades or understanding of students towards the grammar structure that has been identified in the academic text. While the result of the t-test results shown the following.

Table 3. t-Test: Paired Two Sample for Means

\begin{tabular}{lll}
\hline & Pre-test & Post-test \\
\hline Mean & 49.04 & 82.6 \\
Variance & 46.3733 & 20.25 \\
Observations & 25 & 25 \\
Pearson Correlation & -0.1191 & \\
Hypothesized Mean Difference & 0 & \\
df & 24 & \\
t Stat & -19.5164 & \\
P $(\mathrm{T}<=t)$ one-tail & 1.5594 & \\
t Critical one-tail & 1.71088 & \\
$\mathrm{P}(\mathrm{T}<=t)$ two-tail & 3.1188 & \\
$\mathrm{t}$ Critical two-tail & 2.06389 & \\
\hline
\end{tabular}

Table 2 concluded that $\mathrm{t}$ Stat $<\mathrm{t}$-table $(-19.5164<2.0638)$. It can be said that Ho is rejected and $\mathrm{H}_{1}$ is accepted. It means that academic text is effective to increase students' comprehending on English grammar.

\section{Discussion}

The results of data analysis indicate changes in the ability to understand advanced grammar subject. This can be seen from the average score that has been obtained after the learning process is given treatment using academic texts showing an increase of $40 \%$. This is also supported by an increase in the score of each individual. The dominant score is 85 , while the highest score is 90 . Spreading of grades, when students have not been treated with academic texts, grammar test scores are in grades $\mathrm{C}$ and $\mathrm{D}$. While after the grammar learning process is equipped with academic text media, students have increased comprehending of the grammar that exists in the text. Test scores after learning to use academic text media have increased quite well. 18 students have scored in grade $\mathrm{A}$ and 7 people in grade $\mathrm{B}$, it means that there are $72 \%$ who have experienced an increase in grades.

The grammar learning process becomes part of the learning process that is considered difficult and saturating by students. Especially for postgraduate students, they are required to understand more varied grammatical structures. Every student working on grammatical tree structure questions often becomes difficult. However, when the grammar learning process is facilitated using academic texts to create a grammar structure tree it has made it easy for students. The grammar mastery has given rise to the mastery of English vocabulary that can have a wider impact on other English language skills. Another impact of mastering good grammar on language skills 
is understanding reading content because this study uses academic texts. It has found that grammar knowledge contributes to effectiveness in reading comprehension L2 (Akbari, 2014). It has the relationship between vocabulary proficiency and grammar.

From the results of the data analysis, the assumption that the grammar learning process is part of the learning process which is considered difficult and saturating by students has been resolved with the use of appropriate learning media. The academic text is taken from the TOEFL book has a very good formal grammar structure, so that the text helps students not only understand English grammar structure well, but students have improved components of phonological forms, lexical forms, morphosyntactic forms, cohesive forms, information management forms, and interactional forms.

Thus, postgraduate students can achieve learning objectives in advanced grammar courses. Students already have a more varied level of grammar understanding and can identify in academic texts. Every student did the grammatical tree structure questions that often becomes difficult. However, when the grammar learning process is facilitated using academic texts to create a grammar structure tree, it has made it easy for students. The grammar mastery has given rise to the mastery of English vocabulary that can have a wider impact on other English language skills. Another impact of mastering good grammar on language skills is understanding reading content because this study uses academic texts. It has been found that grammar knowledge contributes to effectiveness in reading comprehension L2 (Akbari, 2014). It has a relationship between vocabulary proficiency and grammar.

In this study, grammar learning activities in implementing academic texts for grammar learning processes have been carried out with stages that establish cooperation and sequential learning process sequences. It is relevant to Willis and Willis (1996) suggest various grammar improvement activities including: 1) Identification/consolidation: Students are asked to look for a set of data to identify certain patterns or uses and language forms associated with it; 2) Classification (semantic; structural): Students are asked to work with a data set and sort them according to similarities and differences based on formal or semantic criteria; 3) Constructing/examining hypotheses: Students are given (or asked to make) generalizations about language and are asked to check this against more language data; 4) Cross-language exploration: Students are encouraged to find similarities and differences between patterns in their language and patterns in English; 5) Reconstruction/deconstruction: Students are asked to manipulate language in a way, which expresses the underlying pattern; 6) Remember: Students are asked to remember and reconstruct text elements. The purpose of the recall is to highlight significant features of the text; and 7) Reference training: Students need to learn to use reference works - dictionaries, grammar and study guides.

These activities have helped the students in grammar activities learning. Therefore, every student and teacher must have an awareness of the role of grammar in the mastery of vocabulary. Research shows that both teachers and students are not aware of the potential value of grammar and vocabulary awareness enhancement activities included in books (Afshar \& Bagherieh, 2014). Grammar teaching has found new aspiration with the use of the Internet. There are numerous lively 
and attractive activities, games, puzzles, and worksheets available on the Internet for teachers' as well as students' use. Foreign language teachers, like most teachers in other fields, believe in the power of the Internet as tools and resource banks of various educational materials. Teachers are also experiencing growth in various types of online material that can be directly used in their language classrooms. Therefore, teachers must be careful about the nature of such online material because they will surely create boredom on the part of students while continuing the tradition of living rules-based grammar. Instead, this will make young students dissatisfied with online material whose results may refrain from using it at all (Arikan, 2014).

In this study also has provided variations in the source of academic texts as a medium for grammar learning. Text selection activities are carried out very carefully to meet the needs of students' skills in mastering grammar. Learners of English as a foreign language (EFL) are often found to be much more successful when grammar is introduced through data that is informed by the corpus, which promotes inductive learning in such a way that students do not only obtain grammar through observing language data and self-learning (Phoocharoensil, 2012). The use of student language is to reflect the use of their language, has been suggested as a learning technique that is useful for facilitating second language learning (L2) (Ishikawa, 2018). The mastery of written language which is reflected by the mastery of grammar has given a different conclusion. Students can harmonize the ability to master grammar in learning English.

\section{Conclusion}

The results of the study concluded that students are more interested in learning through the process of practice. This is evident from the implementation of academic texts in learning English grammar. Provision of academic texts for learning grammar also has implications for improving English reading comprehension skills. Because during the process of learning grammar or identifying grammar structures, students indirectly understand the meaning of each vocabulary and the content or content of the reading. Test results have also shown that students have a significant increase in grades. Therefore, the results of this study suggest that teachers can have the right learning media so that learning objectives can be achieved. Research activities can be further developed to link the ability to master grammar, reading skills, and mastery of grammar.

\section{Acknowledgements}

Researchers would like to thank the students who have been involved and helped the research process and all parties who have become sources of reference.

\section{References}

Afshar, H. S., \& Bagherieh, M. (2014). An Evaluation of Grammar and Vocabulary Consciousness-raising Activities in Current ELT Materials. Procedia - Social and Behavioral Sciences, 136, 109-113. https://doi.org/10.1016/J.SBSPRO.2014.05.298

Akbari, Z. (2014). The Role of Grammar in Second Language Reading Comprehension: Iranian ESP Context. Procedia - Social and Behavioral Sciences, 98, 122-126. https://doi.org/10.1016/J.SBSPRO.2014.03.397 
Al-Mekhlafi, A. M., \& Nagaratnam, R. P. (2011). Difficulties in teaching and learning grammar in an efl context. International Journal of Instruction, 4(2), 69-92.

Arikan, A. (2014). An Examination of Online Grammar Teaching Materials Available for Young Learners. Procedia - Social and Behavioral Sciences, 158, 18-22. https://doi.org/10.1016/J.SBSPRO.2014.12.026

Batstone, R., \& Ellis, R. (2009). Principled grammar teaching. System, 37(2), 194-204. https://doi.org/10.1016/J.SYSTEM.2008.09.006

Brown, K., \& Kachru, Y. (2006). Pedagogical Grammars: Second Language. Encyclopedia of Language \& Linguistics, 248-254. https://doi.org/10.1016/B0-08-044854-2/00617-9

Ishikawa, M. (2018). Written languaging, learners' proficiency levels and L2 grammar learning. System, 74, 50-61. https://doi.org/10.1016/J.SYSTEM.2018.02.017

Myhill, D., Jones, S., \& Watson, A. (2013). Grammar matters: How teachers' grammatical knowledge impacts on the teaching of writing. Teaching and Teacher Education, 36, 77-91. https://doi.org/10.1016/J.TATE.2013.07.005

Nassaji, H., \& Fotos, S. (2011). Teaching Grammar in Second Language Classrooms, Integrating Form-Focused Instruction in Communicative Context. London \& New York: Routledge.

Nazari, N. (2013). The effect of implicit and explicit grammar instruction on learners' achievements in receptive and productive modes. Procedia - Social and Behavioral Sciences, 70, 156-162. https://doi.org/10.1016/J.SBSPRO.2013.01.051

Nurhayati, I. (2015). Interlanguage: grammatical errors on students' recount texts (A Case Study of First Year of MAN 2 Banjarnegara in the Academic Year 2014/2015). ELT Forum: Journal of English Language Teaching, 4(1). https://doi.org/10.15294/ELT.V4I1.7918

Phoocharoensil, S. (2012). Language Corpora for EFL Teachers: An Exploration of English Grammar through Concordance Lines. Procedia - Social and Behavioral Sciences, 64, 507514. https://doi.org/10.1016/J.SBSPRO.2012.11.060

Purpura, J. (2004). Assessing Grammar. Cambridge: Cambridge University Press.

Robertson, M., Macdonald, S., Starks, D., \& Nicholas, H. (2018). Enabling change in EFL teachers' ideologies about grammar and grammar teaching through alternative pedagogies. System, 72, 75-84. https://doi.org/10.1016/J.SYSTEM.2017.11.002

Robinson, R. S. (2014). Purposive Sampling. In Encyclopedia of Quality of Life and Well-Being Research (pp. 5243-5245). Dordrecht: Springer Netherlands. https://doi.org/10.1007/978-94007-0753-5_2337

Sik, K. (2015). Tradition or modernism in grammar teaching: Deductive vs. Inductive Approaches. Procedia - Social and Behavioral Sciences, 197, 2141-2144. https://doi.org/10.1016/J.SBSPRO.2015.07.340

Su, H., \& Zhang, L. (2020). Local grammars and discourse acts in academic writing: A case study of exemplification in Linguistics research articles. Journal of English for Academic Purposes, 43, 100805. https://doi.org/10.1016/J.JEAP.2019.100805

Teruya, K. (2009). Grammar as a gateway into discourse: A systemic functional approach to Subject, Theme, and logic. Linguistics and Education, 20(1), 67-79. 
https://doi.org/10.1016/J.LINGED.2009.01.008

Willis, D., \& Willis, J. (1996). Consciousness-raising Activities. Challenge and Change in Language Teaching. Heinemann. 